\title{
EFFECT OF THE PERIOD OF THE YEAR WHICH EXPLANTS WERE COLLECTED ON SHOOT GROWTH AND THE CALLUS FORMATION OF THE TISSUE CULTURED JACK FRUIT
}

\author{
K A H K Kasthuri Arachchi and W T P S K Senarath \\ Department of Botany, University of Sri Jayewardenepura, \\ Nugegoda.
}

\begin{abstract}
A method for rapid propagation of malure Jack fruit from apical meristem culture was developed. Apical meristems were established in Modified Camplell and Durnan medium supplemented wilh NAA and IBA. Cultures were sub cultured in every 4 weeks interval in order to reduce the accumulation of phenolic compounds. Reducing the accumulated phenolics at the base of the explant conhanced the growth rate. There was a significant difference in the growth performance of shoots and callus produced aceording to the period of the year in which explants were collected.
\end{abstract}

60\% of the apical meristems cultured in modified CD medium supplemented with IBA and NAA produced shoots in November to December period. It was only $30 \%$ when the apices were cultured in April to Maty months and decreased to $20 \%$ in June - July months. The shoots produced in November - December period showed a higher vigour (in number of leaves per shoot. mean leaf width and mean shoot length) than those produced in other months. Since jack fruit show seasonal changes in fruit bearing and shedding of leaves, it can be suggested that the difference in growth performances of tissues cultured in artificial culture media would have been effected by endogenous rhythms. It has been observed that the callus production depends on the incubation temperature. Callus was induced at the base of the shoot by increasing the incubation temperature from $25 \pm 1^{11} \mathrm{C}$ to $30 \pm 1^{11} \mathrm{C}$. Growth of the callus was also retarded by accumulated phenolic compounds in the medium. 